\title{
PENERAPAN PEMBELAJARAN TGT BERBANTU MEDIA MONOPOLI UNTUK MENINGKATKAN AKTIVITAS BELAJAR AKUNTANSI SISWA SMKN 1 PENGASIH
}

\section{THE IMPLEMENTATION OF TGT LEARNING WITH MONOPOLY MEDIA TO IMPROVE STUDENT'S ACCOUNTING LEARNING ACTIVITY AT SMKN 1 PENGASIH}

\author{
Oleh: \\ Ari Pratiwi \\ Prodi Pendidikan Akuntansi Universitas Negeri Yogyakarta \\ aripratiwi1905@gmail.com \\ Sukanti \\ Staf Pengajar Jurusan Pendidikan Akuntansi Universitas Negeri Yogyakarta
}

\begin{abstract}
Abstrak
Penelitian Tindakan Kelas ini bertujuan untuk meningkatkan Aktivitas Belajar Akuntansi Siswa Kelas XI AK2 SMK Negeri 1 Pengasih Tahun Ajaran 2016/2017 melalui Penerapan Model Pembelajaran Kooperatif Tipe Teams Games Tournament (TGT) Berbantu Media Monopoli. Subjek dalam penelitian ini adalah Siswa Kelas XI AK2 1 SMK Negeri 1 Pengasih Tahun Ajaran 2016/2017 yang berjumlah 32 siswa. Instrumen data yang digunakan yaitu lembar observasi dan catatan harian guru. Analisis data yang digunakan adalah analisis data deskriptif kuantitatif dengan persentase. Hasil penelitian ini menunjukkan bahwa Penerapan Model Pembelajaran Kooperatif Tipe Teams Games Tournament (TGT) Berbantu Media Monopoli dapat meningkatkan Aktivitas Belajar Akuntansi Siswa Kelas XI AK2 SMK Negeri 1 Pengasih Tahun Ajaran 2016/2017. Dibuktikan dengan adanya peningkatan setiap indikator Aktivitas Belajar Akuntansi dari sikus I ke siklus II. Peningkatan skor ratarata Aktivitas Belajar Akuntansi sebesar 17,86\% (relatif) dan 13,87\% (absolut) dari siklus I sebesar $77,68 \%$ menjadi sebesar $91,55 \%$ pada siklus II.
\end{abstract}

Kata Kunci: Teams Games Tournament (TGT), Media Monopoli, Aktivitas Belajar Akuntansi

\begin{abstract}
This classroom action research aims to improve Student's Accounting Learning Activity in class XI AK2 at SMK Negeri 1 Pengasih Academic Year of 2016/2017 through the implementation of Cooperative Learning Model Type Teams Games Tournament Assisted Monopoly Media. The subject of this research is the students of Class XI AK2 at SMK Negeri 1 Pengasih Academic Year of 2016/2017 some thirty two's student. The data instrument was used observations sheet and teachers daily note. Data analysis is a data deskripstif type percentages. The results showed that the implementation of Cooperative Learning Model Type Teams Games Tournament Assisted Monopoly Media can improve Student's Accounting Learning Activity of Students in Class XI AK2 at SMK Negeri 1 Pengasih Academic Year of 2016/2017. Evidenced by an increase in each indicators being Accounting Learning Activity from cycle I to cycle II. Increased in the average score of Accounting Learning Activity at the amount of 17,86\% (relative) and 13,87\% (absolute) from cycle I at the amount 77,68\% increase to be $91,55 \%$ in cycle II.
\end{abstract}

Key Words: Teams Games Tournament (TGT), Monopoly Media, Accounting Learning Activity 


\section{PENDAHULUAN}

Pendidikan memegang peranan yang sangat penting untuk menjamin kelangsungan hidup bangsa dan negara. Pendidikan merupakan wahana untuk meningkatkan dan mengembangkan kualitas Sumber Daya Manusia (SDM). Sistem pendidikan yang baik pada suatu negara akan mampu menghasilkan SDM yang berkualitas, dapat diandalkan, kompeten, profesional dalam bidangnya, serta memiliki kemandirian sebagai modal untuk bersaing dengan dunia luar.

Pendidikan dapat diartikan sebagai usaha untuk menciptakan manusia yang berkepribadian dan sesuai dengan nilai-nilai yang berlaku dalam masyarakat sehingga dapat memajukan kehidupan masyarakat tersebut. Menurut Undang-Undang Republik Indonesia Nomor 20 Tahun 2003 tentang Sistem Pendidikan Nasional, Bab I Pasal 1 ayat (1): Pendidikan adalah usaha sadar dan terencana untuk mewujudkan suasana belajar dan proses pembelajaran agar peserta didik secara aktif mengembangkan potensi dirinya untuk memiliki kekuatan spiritual keagamaan, pengendalian diri, kepribadian, kecerdasan, akhlak mulia, serta keterampilan yang dibutuhkan bagi dirinya, masyarakat, bangsa dan negara.

George F. Kneller dalam Arif Rohman (2013: 7-8) melihat pendidikan dalam tiga cakupan yaitu luas, teknis, dan hasil. Dalam arti luas, pendidikan adalah menunjuk pada suatu tindakan atau pengalaman yang mempunyai pengaruh yang berhubungan dengan pertumbuhan atau perkembangan pikiran (mind), watak (character) dan kemampuan fisik (physical ability) individu. Dalam arti teknis, pendidikan adalah proses di mana masyarakat, melalui lembaga-lembaga pendidikan (sekolah, perguruan tinggi, atau lembaga-lembaga lain), dengan sengaja mentransformasikan warisan kebudayaannya, yaitu pengetahuan, nilainilai dan keterampilan-keterampilan, dari generasi ke generasi, sedangkan dalam arti hasil, pendidikan adalah apa yang kita peroleh melalui belajar (pengetahuan, nilainilai dan keterampilan).

Salah satu permasalahan yang dihadapi bangsa Indonesia saat ini adalah masih rendahnya kualitas pendidikan. Berbagai upaya telah dilakukan oleh pemerintah untuk memperbaiki mutu pendidikan di Indonesia, antara lain melalui berbagai pelatihan dan peningkatan kualitas guru, penyempurnaan kurikulum, pengadaan buku dan alat pengajaran, serta perbaikan sarana dan prasarana pendidikan. Namun demikian mutu pendidikan yang dicapai belum seperti yang diharapkan. Perbaikan yang telah dilakukan pemerintah tidak akan ada artinya tanpa dukungan dari guru, orang tua, siswa, dan masyarakat.

Untuk meningkatkan mutu pendidikan diperlukan kombinasi yang sinergis antara berbagai komponen pendidikan untuk mencapai tujuan pembelajaran. Adapun komponen-komponen tersebut antara lain: (a) tujuan pendidikan; (b) peserta didik; (c) pendidik; (d) isi pendidikan; (e) metode pendidikan; (f) alat pendidikan; dan (g) lingkungan pendidikan (Dwi Siswoyo, dkk. 2013: 75). Apabila semua komponen tersebut dapat bekerjasama secara maksimal maka kegiatan belajar mengajar akan berjalan lancar dan diharapkan tujuan pembelajaran dapat tercapai sehingga kualitas pendidikan dapat meningkat.

Dari ketujuh komponen komponen tersebut terdapat dua komponen pembelajaran yang sangat penting dari yang lainnya, yaitu guru dan siswa. Pembelajaran pada hakikatnya adalah proses interaksi antara guru dengan siswa. Oleh sebab itu, untuk menciptakan interaksi pembelajaran yang efektif guru harus mampu memilih metode pembelajaran yang tepat dan menarik sehingga siswa termotivasi untuk belajar dan dapat mendorong terjadinya aktivitas belajar yang tinggi.

Belajar merupakan suatu kumpulan berbagai aktivitas, sehingga aktivitas merupakan aspek terpenting dalam belajar. Tidak akan ada pembelajaran apabila tidak 
ada aktivitas yang dilakukan. Agar tercipta suasana belajar yang dapat mendorong aktivitas belajar siswa, guru harus menjadikan siswa sebagai subjek pembelajaran, bukan hanya objek. Untuk itu diperlukan adanya pembelajaran yang berpusat pada siswa. Hal ini dimaksudkan agar terjalin interaksi yang baik antara guru dan siswa dalam kegiatan pembelajaran, sehingga transfer ilmu yang diberikan guru dapat diterima dengan mudah oleh siswanya. Tanpa adanya aktivitas belajar siswa tujuan pembelajaran tidak akan tercapai dengan maksimal. Berdasarkan hal tersebut, maka aktivitas belajar merupakan salah satu faktor penting dalam mencapai keberhasilan pembelajaran.

Berdasarkan hasil observasi yang peneliti lakukan pada tanggal 19 Mei 2016 pada saat jam pelajaran Akuntansi Perusahaan Jasa di kelas X AK2 SMK Negeri 1 Pengasih, Kegiatan Belajar Mengajar (KBM) yang digunakan masih menggunakan ceramah dan latihan. Metode ini menimbulkan kebosanan yang dirasakan siswa saat menerima pelajaran. Berdasarkan hasil observasi tersebut, dari 32 siswa, hanya 17 siswa atau 53\% yang terlibat aktif dalam kegiatan belajar mengajar, sedangkan sisanya 15 siswa atau $47 \%$ lebih banyak menggunakan kesempatan tersebut untuk bermain dengan temannya atau melakukan aktivitas lain yang tidak berkaitan dengan materi yang sedang diajarkan guru. Berdasarkan ilustrasi tersebut menunjukkan bahwa siswa bosan dan kurang aktif dalam mengikuti pelajaran. Hal tersebut disebabkan karena guru belum memilih metode pembelajaran yang didesain untuk meningkatkan Aktivitas Belajar Akuntansi, sehingga siswa cenderung melampiaskan aktivitasnya pada berbagai hal yang tidak ada hubungannya dengan materi pelajaran.

Jika kondisi tersebut terus dibiarkan, dikhawatirkan tujuan pembelajaran tidak akan tercapai dengan maksimal. Untuk mengatasi permasalahan tersebut, perlu adanya pemilihan metode pembelajaran yang dapat menarik perhatian siswa sehingga dapat meningkatkan Aktivitas Belajar Akuntansi.

Pemilihan metode pembelajaran yang tepat bertujuan agar tujuan pembelajaran atau indikator pencapaian kompetensi dapat dicapai secara maksimal. Metode pembelajaran yang dipilih sebaiknya disesuaikan dengan situasi dan kondisi siswa, bahan pelajaran atau materi yang akan disampaikan, dan tujuan pengajaran yang akan dicapai. Salah satu model pembelajaran yang dapat dikembangkan oleh guru adalah model pembelajaran kooperatif. Model pembelajaran kooperatif ini merupakan salah satu model pembelajaran yang melibatkan peran aktif siswa dalam kegiatan belajar mengajar.

Model pembelajaran kooperatif adalah rangkaian kegiatan belajar yang dilakukan oleh siswa dalam kelompokkelompok tertentu untuk mencapai tujuan pembelajaran yang telah ditentukan. Ada empat unsur penting dalam model pembelajaran kooperatif yaitu: (1) adanya peserta dalam kelompok; (2) adanya aturan dalam kelompok; (3) adanya upaya belajar setiap anggota kelompok; dan (4) adanya tujuan yang harus dicapai. (Wina Sanjaya, $2014: 241$ ).

Menurut Robert E. Slavin (2010: 1117) terdapat beberapa macam model pembelajaran kooperatif antara lain Student Teams Achievement Division (STAD), Teams Games Tournament (TGT), Jigsaw II, Teams Accelerated Instruction (TAI), dan Cooperative Integrated Reading and Composition (CIRC). Salah satu model pembelajaran kooperatif yang dapat diterapkan guru untuk meningkatkan Aktivitas Belajar Akuntansi adalah Model Pembelajaran Kooperatif Tipe Teams Games Tournament (TGT). Model pembelajaran ini dapat mengurangi ketergantungan siswa kepada guru, mengembangkan kemampuan mengungkapkan ide dan gagasan, membantu memberdayakan siswa lebih bertanggung jawab dalam belajar, dan meningkatkan aktivitas belajar siswa (Wina Sanjaya, 2014: 240-250). 
Teams Games Tournaments (TGT) merupakan salah satu jenis model pembelajaran kooperatif yang menggunakan turnamen akademik, dengan menggunakan kuis-kuis dan sistem skor kemajuan individu, di mana para siswa berlomba sebagai wakil tim mereka dengan anggota tim lain yang kinerja akademik sebelumnya setara seperti mereka (Robert E.Slavin, 2010: 163). Model pembelajaran ini menawarkan suasana yang menyenangkan dalam kegiatan pembelajaran yang dikemas dalam bentuk turnamen atau kompetisi yang pada akhirnya diharapkan aktivitas belajar siswa dapat mengalami peningkatan.

Permainan yang akan digunakan dalam implementasi Model Pembelajaran Kooperatif Tipe TGT ini adalah Monopoli. Permainan Monopoli ini telah dimodifikasi dengan materi pembelajaran akuntansi, di mana setiap petak telah disediakan pertanyaan-pertanyaan sesuai dengan materi yang sedang dipelajari. Setiap siswa harus siap untuk menjawab pertanyaan tersebut agar mendapatkan skor maksimal dalam permainan tersebut. Penerapan Model Pembelajaran Kooperatif tipe TGT Berbantu Media Monopoli ini memungkinkan siswa dapat belajar lebih rileks, menyenangkan, menumbuhkan tanggung jawab, kerjasama, persaingan sehat antar siswa, serta meningkatkan Aktivitas Belajar Akuntansi.

Dari segi teoritis, Model Pembelajaran Kooperatif Tipe TGT Berbantu Media Monopoli memiliki keunggulan dibandingkan dengan model pembelajaran konvensional, sehingga peneliti tertarik untuk melakukan penelitian tindakan kelas dengan judul "Penerapan Model Pembelajaran Kooperatif Tipe Teams Games Tournament (TGT) Berbantu Media Monopoli untuk Meningkatkan Aktivitas Belajar Akuntansi Siswa Kelas XI AK2 SMK Negeri 1 Pengasih Tahun Ajaran 2016/2017".

\section{METODE PENELITIAN Jenis Penelitian}

Penelitian ini merupakan penelitian tindakan kelas (Classroom Action Research) yang bersifat kolaboratif dan partisipatif antara peneliti dan guru, khususnya guru Mata Pelajaran Akuntansi Perusahaan Dagang SMK Negeri 1 Pengasih.

\section{Waktu dan Tempat Penelitian}

Penelitian ini dilakukan di Kelas XI AK2 SMK Negeri 1 Pengasih yang beralamat di Jalan Kawijo 11 Pengasih, Kulon Progo. Penelitian ini dilaksanakan pada bulan Juli sampai bulan Agustus 2016.

\section{Target/Subjek Penelitian}

Subjek penelitian ini adalah Siswa Kelas XI AK2 SMK Negeri 1 Pengasih Tahun Ajaran 2016/2017 yang berjumlah 32 siswa.

\section{Rancangan Penelitian}

Penelitian ini dilakukan dalam dua siklus yang meliputi:

a. Siklus I

1) Perencanaan Tindakan

Pada tahap ini peneliti menyiapkan segala sesuatu yang dibutuhkan saat pelaksanaan, seperti:

a) Pembuatan RPP

b) Membuat pedoman observasi

c) Menyiapkan format catatan lapangan

d) Menyusun materi pembelajaran mengenai Jurnal Khusus.

e) Menyusun soal-soal turnamen beserta kunci jawaban.

f) Membagi siswa menjadi beberapa tim

g) Menyiapkan perlengkapan penunjang Model Pembelajaran Kooperatif Tipe TGT Berbantu Media Monopoli.

2) Pelaksanaan Tindakan

a) Tahap Mengajar (Teaching)

Dalam tahap ini guru mengajarkan materi pelajaran secara garis besar, biasanya 


$\begin{array}{lr}\text { dengan } & \text { pengajaran } \\ \text { langsung/ceramah } & \text { maupun } \\ \text { dengan diskusi yang } & \text { dipimpin } \\ \text { oleh guru. }\end{array}$

b) Belajar Tim (Teams Study)

Dalam tahap ini siswa dibagi menjadi tim yang terdiri dari 4 orang dengan kemampuan yang heterogen. Tugas mereka di sini adalah menyelesaikan soal diskusi yang diberikan oleh guru dan saling membelajarkan antar anggota.

c) Games

Games ini menggunakan permainan Monopoli. Di sini mereka diberikan satu set permainan Monopoli dan diberikan waktu untuk bermain bersama kelompoknya.

d) Tournament

Dalam tournament ini masingmasing kelompok mewakilkan anggotanya untuk maju ke tournament yang telah disediakan untuk bermain Monopoli. Mereka akan bersaing dengan perwakilan kelompok lain untuk memperoleh Uang Monopoli sebanyak mungkin. Uang itu akan diakumulasikan dengan uang masing-masing anggota tim. Tim dengan jumlah uang yang paling banyak akan keluar sebagai pemenang dan mendapatkan hadiah.

3) Pengamatan

Peneliti dibantu tiga orang observer mengamati proses pembelajaran dengan berpedoman pada lembar observasi Aktivitas Belajar Akuntansi yang telah dipersiapkan agar data yang diperoleh lebih akurat untuk perbaikan pada siklus berikutnya.

4) Refleksi

Tahap refleksi merupakan kegiatan yang dilakukan untuk mengetahui kelebihan dan kekurangan proses pembelajaran yang telah dilakukan. Guru bersama peneliti dapat mencari solusi terhadap masalah-masalah yang mungkin timbul pada siklus II agar dapat dibuat rencana perbaikan dari siklus I.

b. Siklus II

Adapun kegiatan yang dilakukan pada siklus II ini pada intinya sama dengan kegiatan yang dilakukan pada siklus I, namun kegiatan yang dilakukan di siklus II ini mengacu atau berpedoman pada refleksi pada siklus I dengan tujuan agar peneliti dapat memperbaiki tindakan dan pelaksanaan pembelajaran di siklus II, serta indikator keberhasilan yang diharapkan akan tercapai.

\section{Teknik Pengumpulan Data}

a. Observasi Partisipatif

Teknik observasi ini digunakan untuk mengumpulkan data mengenai Aktivitas Belajar Akuntansi. Observasi dilakukan selama proses pembelajaran berlangsung yang dilakukan oleh peneliti dan dibantu oleh 3 orang observer.

b. Catatan Lapangan

Catatan lapangan digunakan untuk memperoleh data berbagai aspek pembelajaran di kelas, suasana kelas, pengelolaan kelas, hubungan interaksi guru dengan siswa, dan interaksi siswa dengan siswa selama proses pembelajaran dengan penerapan Model Pembelajaran Kooperatif Tipe Teams Games Tournament (TGT) Berbantu Media Monopoli.

c. Dokumentasi

Dokumen yang dapat membantu dalam mengumpulkan data penelitian ini yaitu silabus sebagai dasar untuk membuat RPP serta daftar siswa dan daftar nilai siswa sebagai dasar untuk membentuk kelompok belajar yang akan digunakan dalam pembelajaran akuntansi dengan Model Pembelajaran Kooperatif Tipe Teams Games Tournament (TGT) Berbantu Media Monopoli. 


\section{Instrumen Penelitian}

a. Pedoman Observasi

Pedoman observasi Aktivitas Belajar Akuntansi berisi pedoman pengamatan aktivitas yang terjadi selama pembelajaran di dalam kelas. Berikut ini indikator Aktivitas Belajar Akuntansi yang akan diteliti:

Tabel 1. Kisi-kisi Observasi Aktivitas Belajar Akuntansi

\begin{tabular}{|c|c|c|c|}
\hline No & Aspek & & Uraian Indikator \\
\hline \multirow[t]{2}{*}{1} & \multirow[t]{2}{*}{$\begin{array}{c}\text { Aktivitas } \\
\text { visual }\end{array}$} & $\mathrm{a}$ & $\begin{array}{l}\text { Siswa } \\
\text { memperhatikan } \\
\text { penjelasan dari guru } \\
\text { saat presentasi materi } \\
\text { pelajaran }\end{array}$ \\
\hline & & $\mathrm{b}$ & $\begin{array}{l}\text { Siswa membaca } \\
\text { materi pembelajaran } \\
\text { Akuntansi }\end{array}$ \\
\hline \multirow{3}{*}{2} & \multirow{3}{*}{$\begin{array}{c}\text { Aktivitas } \\
\text { lisan }\end{array}$} & $\mathrm{c}$ & $\begin{array}{l}\text { Siswa mengajukan } \\
\text { pertanyaan kepada } \\
\text { guru saat KBM atau } \\
\text { saat siswa dalam } \\
\text { kegiatan kelompok }\end{array}$ \\
\hline & & $\mathrm{d}$ & $\begin{array}{lr}\text { Siswa } & \text { memberi } \\
\text { jawaban, } & \text { saran, } \\
\text { pendapat, } & \text { atau } \\
\text { komentar } & \text { kepada } \\
\text { guru atau teman }\end{array}$ \\
\hline & & $\mathrm{e}$ & $\begin{array}{l}\text { Siswa berdiskusi } \\
\text { dengan teman saat } \\
\text { belajar kelompok }\end{array}$ \\
\hline \multirow{2}{*}{3} & \multirow{2}{*}{$\begin{array}{l}\text { Aktivitas } \\
\text { mendengar }\end{array}$} & $\mathrm{f}$ & $\begin{array}{l}\text { Siswa mendengarkan } \\
\text { penjelasan guru pada } \\
\text { saat kegiatan } \\
\text { presentasi materi } \\
\text { pembelajaran }\end{array}$ \\
\hline & & $\mathrm{g}$ & $\begin{array}{l}\text { Siswa mendengarkan } \\
\text { penjelasan teman } \\
\text { pada saat kegiatan } \\
\text { belajar tim dan } \\
\text { games tournament }\end{array}$ \\
\hline 4 & $\begin{array}{l}\text { Aktivitas } \\
\text { menulis }\end{array}$ & $\mathrm{h}$ & $\begin{array}{lr}\text { Siswa mencatat } \\
\text { materi } & \text { yang } \\
\text { disampaikan } & \text { oleh } \\
\text { guru saat presentasi } \\
\text { materi pembelajaran }\end{array}$ \\
\hline
\end{tabular}

\begin{tabular}{|c|c|c|c|}
\hline No & Aspek & & Uraian Indikator \\
\hline & & $\mathrm{i}$ & $\begin{array}{lr}\text { Siswa } & \text { mengerjakan } \\
\text { latihan } & \text { yang } \\
\text { diberikan guru dalam } \\
\text { kegiatan } \\
\text { kelompok }\end{array}$ \\
\hline & & $\mathrm{j}$ & $\begin{array}{l}\text { Siswa menjawab } \\
\text { pertanyaan (menulis) } \\
\text { saat } \\
\text { tournament dengan } \\
\text { Media Monopoli }\end{array}$ \\
\hline
\end{tabular}

Pedoman penskoran Aktivitas Belajar Akuntansi dengan Model Pembelajaraan Kooperatif Tipe TGT Berbantu Media Monopoli yaitu sebagai berikut:

Tabel 2. Pedoman penskoran Aktivitas Belajar Akuntansi

\begin{tabular}{|l|l|}
\hline $\begin{array}{l}\text { Kategori Setiap } \\
\text { Indikator }\end{array}$ & $\begin{array}{l}\text { Skor } \\
\text { Penilaian }\end{array}$ \\
\hline Aktif & 2 \\
\hline Cukup Aktif & 1 \\
\hline Tidak Aktif & 0 \\
\hline
\end{tabular}

b. Catatan Lapangan

Catatan lapangan digunakan untuk menuliskan berbagai kejadian yang berhubungan dengan penelitian yang terjadi di dalam kelas, berupa interaksi yang terjadi antara siswa dengan guru, interaksi antar siswa, pengelolaan kelas dan suasana kelas.

\section{Teknik Analisis Data}

Teknik analisis data yang digunakan yaitu analisis data deskriptif kuantitatif dengan persentase. Analisis ini dilakukan dengan:

a. Mengolah skor Aktivitas Belajar Akuntansi

1) Membuat kategori penyekoran Aktivitas Belajar Akuntansi.

2) Menghitung dan menjumlahkan skor Aktivitas Belajar Akuntansi pada masing-masing siswa.

3) Menghitung persentase skor Aktivitas Belajar Akuntansi secara individual dengan rumus: $\frac{\text { Jumlah skor pada setiap siswa }}{\text { Skor Maksimum tiap siswa }} \times 100 \%$ 
4) Menghitung dan menjumlahkan skor untuk masing-masing indikator Aktivitas Belajar Akuntansi yang diamati.

5) Menghitung skor Aktivitas Belajar Akuntansi pada setiap indikator yang diamati dengan rumus :

Jumlah skor pada setiap indikator

$$
\text { Skor Maksimum } x 100 \%
$$

6) Menghitung persentase rata-rata skor Aktivitas Belajar Akuntansi dengan rumus:

$$
\frac{\text { Skor total Aktivitas Belajar Akuntansi }}{\text { Jumlah Indikator }} \times 100 \%
$$

7) Menghitung peningkatan persentase Aktivitas Belajar Akuntansi

a) Peningkatan persentase absolut Keterangan: Peningkatan Absolut $=B-A$

B : Persentase skor siklus II

A : Persentase skor siklus I

b) Peningkatan persentase relatif

Peningkatan Relatif $=\frac{B-A}{A} \times 100 \%$

Keterangan:

B : Persentase skor siklus II

A : Persentase skor siklus I

b. Menyajikan Data

Setelah data mengenai Aktivitas Belajar Akuntansi diolah, data tersebut disampaikan secara sederhana dan disajikan dalam bentuk tabel dan grafik sehingga mudah dipahami.

c. Menarik Kesimpulan

Penarikan kesimpulan ini dilakukan dengan tujuan untuk menjawab rumusan masalah yang telah disajikan pada awal penelitian. Setelah data disajikan dalam bentuk tabel dan grafik, kemudian dilakukan pemaknaan data ke dalam pernyataan.

\section{HASIL PENELITIAN PEMBAHASAN \\ Siklus I}

Siklus I dilaksanakan dalam 1 kali pertemuan (@4 x 45 menit). Hal tersebut dikarenakan pertimbangan guru yang beranggapan bahwa 1 kali pertemuan sudah cukup, dan apabila penerapan model TGT ini dilakukan lebih dari satu pertemuan maka siswa mudah merasa jenuh dan bosan.

Tindakan pada Siklus I ini dilaksanakan pada hari Selasa, 26 Juli 2016 pukul 11.15-14.45 WIB. Adapun materi yang dipelajari pada pertemuan ini adalah Jurnal Khusus. Peneliti dibantu oleh tiga orang observer dalam mengamati Aktivitas Belajar Akuntansi. Adapun hasil dari penelitiannya yaitu:

Tabel 3. Hasil Observasi Aktivitas Belajar

\begin{tabular}{|c|c|c|c|}
\hline No & Aspek & Indikator & $\begin{array}{c}\% \\
\text { Aktivitas } \\
\text { per } \\
\text { Indikator }\end{array}$ \\
\hline 1 & \multirow{2}{*}{$\begin{array}{l}\text { Aktivitas } \\
\text { Visual }\end{array}$} & $\mathrm{a}$ & $78,57 \%$ \\
\hline 2 & & $\mathrm{~b}$ & $71,43 \%$ \\
\hline 3 & \multirow{3}{*}{$\begin{array}{l}\text { Aktivitas } \\
\text { Lisan }\end{array}$} & $\mathrm{c}$ & $66,07 \%$ \\
\hline 4 & & $\mathrm{~d}$ & $69,64 \%$ \\
\hline 5 & & $\mathrm{e}$ & $89,29 \%$ \\
\hline 6 & \multirow{2}{*}{$\begin{array}{l}\text { Aktivitas } \\
\text { Mendengar }\end{array}$} & $\mathrm{f}$ & $80,36 \%$ \\
\hline 7 & & $\mathrm{~g}$ & $85,71 \%$ \\
\hline 8 & \multirow{3}{*}{$\begin{array}{l}\text { Aktivitas } \\
\text { Menulis }\end{array}$} & $\mathrm{h}$ & $76,79 \%$ \\
\hline 9 & & $\mathrm{i}$ & $83,93 \%$ \\
\hline 10 & & $\mathrm{j}$ & $75,00 \%$ \\
\hline \multicolumn{3}{|c|}{$\begin{array}{c}\text { Rata-rata Aktivitas Belajar } \\
\text { Akuntansi Siklus I }\end{array}$} & $77,68 \%$ \\
\hline
\end{tabular}
Akuntansi Siklus I

Sumber: Data primer yang diolah

Jika dilihat dari rata-rata Aktivitas Belajar Akuntansi terlihat bahwa secara keseluruhan Aktivitas Belajar Akuntansi telah mencapai 77,68\%. Namun apabila dilihat dari aktivitas per indikator masih terlihat beberapa indikator yang belum mencapai kriteria keberhasilan, yaitu $75 \%$. Oleh karena itu perlu diadakan refleksi untuk pembaikan di siklus II.

\section{Siklus II}

Siklus II dilaksanakan dalam 1 kali pertemuan saja (4x 45 menit) dikarenakan pertimbangan guru yang beranggapan bahwa 1 kali pertemuan sudah cukup, mengingat 
masih banyak materi lain yang harus dipelajari siswa dan dikhawatirkan siswa mudah jenuh dan bosan.

Tindakan pada siklus II ini dilaksanakan pada hari Selasa, 2 Agustus 2016 pukul 11.15-14.45 WIB. Adapun materi yang dipelajari pada pertemuan ini adalah Ketentuan Bisnis Perusahaan Dagang. Peneliti dibantu oleh tiga orang observer dalam mengamati Aktivitas Belajar Akuntansi. Adapun hasil dari penelitiannya yaitu:

Tabel 4. Hasil Observasi Aktivitas Belajar Akuntansi Siklus II

\begin{tabular}{|c|c|c|c|}
\hline No & Aspek & Indikator & $\begin{array}{c}\% \\
\text { Aktivitas } \\
\text { per } \\
\text { Indikator }\end{array}$ \\
\hline 1 & \multirow{2}{*}{$\begin{array}{l}\text { Aktivitas } \\
\text { Visual }\end{array}$} & $\mathrm{a}$ & $93,10 \%$ \\
\hline 2 & & $\mathrm{~b}$ & $86,21 \%$ \\
\hline 3 & \multirow{3}{*}{$\begin{array}{l}\text { Aktivitas } \\
\text { Lisan }\end{array}$} & $\mathrm{c}$ & $81,03 \%$ \\
\hline 4 & & $\mathrm{~d}$ & $84,48 \%$ \\
\hline 5 & & $\mathrm{e}$ & $100,00 \%$ \\
\hline 6 & \multirow{2}{*}{$\begin{array}{l}\text { Aktivitas } \\
\text { Mendengar }\end{array}$} & $\mathrm{f}$ & $94,83 \%$ \\
\hline 7 & & $\mathrm{~g}$ & $96,55 \%$ \\
\hline 8 & \multirow{3}{*}{$\begin{array}{l}\text { Aktivitas } \\
\text { Menulis }\end{array}$} & $\mathrm{h}$ & $91,38 \%$ \\
\hline 9 & & i & $98,28 \%$ \\
\hline 10 & & $\mathrm{j}$ & $89,66 \%$ \\
\hline \multicolumn{3}{|c|}{$\begin{array}{l}\text { Rata-rata Aktivitas Belajar } \\
\text { Akuntansi Siklus II }\end{array}$} & $91,55 \%$ \\
\hline
\end{tabular}

Sumber: Data primer yang diolah

Tabel 4 tersebut menunjukkan bahwa di siklus II rata-rata Aktivitas Belajar Akuntansi telah mencapai 91,55\%. Selain itu seluruh indikator Aktivitas Belajar Akuntansi juga telah mencapai kriteria keberhasilan yaitu $75 \%$, sehingga tindakan diakhiri sampai siklus II.

\section{Pembahasan}

Pelaksanaan penelitian tindakan kelas ini dilakukan sebanyak dua siklus dengan tujuan untuk meningkatkan Aktivitas Belajar Akuntansi Siswa Kelas XI AK2 SMK Negeri 1 Pengasih Tahun Ajaran 2016/2017 melalui penerapan Model Pembelajaran Kooperatif Tipe Teams Games Tournament (TGT)
Berbantu Media Monopoli. Penelitian ini dilatarbelakangi oleh masih rendahnya Aktivitas Belajar Akuntansi Siswa Kelas XI AK2 SMK Negeri 1 Pengasih Tahun Ajaran 2016/2017.

Adapun tahapan dalam pelaksanaan di setiap siklusnya meliputi kegiatan presentasi kelompok, belajar kelompok, games tournament, dan penghargaan kelompok. Pada siklus I, secara keseluruhan proses pembelajaran berjalan dengan baik namun terdapat beberapa kendala seperti belum terbiasanya siswa dalam menerapkan Model Pembelajaran Kooperatif Tipe Teams Games Tournament (TGT) Berbantu Media Monopoli sehingga masih terdapat kebingungan, siswa masih belum banyak yang bertanya kepada guru atau teman, siswa masih belum banyak yang menjawab pertanyaan yang diajukan oleh guru, dan hanya beberapa siswa yang membaca materi pelajaran Akuntansi. Hal tersebut menyebabkan beberapa indikator Aktivitas Belajar Akuntansi pada siklus I belum mencapai kriteria keberhasilan yaitu $75 \%$ sehingga perlu dilanjutkan tindakan pada siklus II.

Adapun indikator Aktivitas Belajar Akuntansi yang masih kurang yaitu siswa membaca materi pelajaran Akuntansi hanya mencapai $71,43 \%$, siswa mengajukan pertanyaan kepada guru saat KBM atau saat siswa dalam kegiatan kelompok hanya mencapai 66,07\%, dan siswa memberi jawaban, saran, pendapat, atau komentar kepada guru atau teman hanya mencapai $69,64 \%$. Selain itu untuk indikator siswa menjawab pertanyaan (menulis) saat games tournament dengan Media Monopoli hasil yang diperoleh masih berada di batas minimum yaitu hanya mencapai $75,00 \%$. Semua permasalahan yang terjadi pada siklus I menjadi bahan refleksi untuk diperbaiki agar siklus II nantinya dapat berjalan dengan baik.

Jika dilihat dari Aktivitas Belajar Akuntansi pada siklus I secara individual, maka akan terlihat pengelompokan siswa 
berdasarkan Aktivitas Belajar Akuntansi seperti tertera di tabel 5 berikut ini:

Tabel 5. Pengelompokan Siswa Berdasarkan Aktivitas Belajar Akuntansi Siklus I

\begin{tabular}{|l|c|c|c|}
\hline Kriteria & $\begin{array}{c}\text { Skor } \\
\text { Aktivitas }\end{array}$ & $\begin{array}{c}\text { Jumlah } \\
\text { Siswa }\end{array}$ & Persentase \\
\hline $\begin{array}{l}\text { Sangat } \\
\text { Rendah }\end{array}$ & $0-4$ & - & $0 \%$ \\
\hline Rendah & $5-8$ & - & $0 \%$ \\
\hline Sedang & $9-12$ & 3 & $10,71 \%$ \\
\hline Tinggi & $13-16$ & 13 & $46,43 \%$ \\
\hline $\begin{array}{l}\text { Sangat } \\
\text { Tinggi }\end{array}$ & $17-20$ & 12 & $42,86 \%$ \\
\hline \multicolumn{2}{|c|}{ Jumlah } & 28 & $100,00 \%$ \\
\hline
\end{tabular}

Tabel 5 tersebut menunjukkan pengelompokan siswa berdasarkan Aktivitas Belajar Akuntansi. Berikut ini akan digambarkan pengelompokan siswa berdasarkan kriteria keberhasilan Aktivitas Belajar Akuntansi yaitu $\geq 75 \%$ atau dengan skor $\geq 15$.

Tabel 6. Pengelompokan

Siswa

Berdasarkan

Kriteria

Keberhasilan Aktivitas Belajar Akuntansi Siklus I

\begin{tabular}{|l|c|c|c|}
\hline Kriteria & $\begin{array}{c}\text { Skor } \\
\text { Aktivitas }\end{array}$ & $\begin{array}{c}\text { Jumlah } \\
\text { Siswa }\end{array}$ & $\begin{array}{c}\text { Persen- } \\
\text { tase }\end{array}$ \\
\hline $\begin{array}{l}\text { Kurang } \\
\text { Aktif }\end{array}$ & $<15$ & 9 & $32 \%$ \\
\hline Aktif & $15-20$ & 19 & $68 \%$ \\
\hline \multicolumn{2}{|c|}{ Jumlah } & 28 & $100 \%$ \\
\hline
\end{tabular}

Berdasarkan tabel 6 tersebut terlihat bahwa masih terdapat beberapa siswa dengan Aktivitas Belajar Akuntansi yang masih rendah, yaitu masih kurang dari $75 \%$. Terdapat 9 siswa dengan Aktivitas Belajar Akuntansi yang masih kurang dari $75 \%$. Jika dilihat dari Aktivitas Belajar Akuntansi secara individual masih perlu diadakan tindakan kelas untuk meningkatkan Aktivitas Belajar Akuntansi, sehingga perlu adanya perbaikan di siklus II.

Pada siklus II, pelaksanaan pembelajaran melihat dari hasil refleksi siklus I dengan tujuan untuk memperbaiki kekurangan pada siklus I sehingga tujuan yang telah ditetapkan dapat tercapai. Penerapan Model Pembelajaran Kooperatif Tipe TGT Berbantu Media Monopoli pada siklus II ini sudah berjalan dengan baik dan kendala-kendala yang ada pada siklus I sudah diperbaiki. Pada siklus II terjadi peningkatan Aktivitas Belajar Akuntansi dibandingkan siklus I. Hal tersebut menunjukkan bahwa tindakan yang dilakukan dapat meningkatkan Aktivitas Belajar Akuntansi sehingga mencapai kriteria keberhasilan.

Adapun indikator yang masih kurang pada siklus I dan sudah meningkat pada siklus II yaitu siswa membaca materi pelajaran Akuntansi meningkat persentasenya menjadi $86,21 \%$, siswa mengajukan pertanyaan kepada guru saat KBM atau saat siswa dalam kegiatan kelompok meningkat persentasenya menjadi $81,03 \%$, siswa memberi jawaban, saran, pendapat, atau komentar kepada guru atau teman meningkat persentasenya menjadi $84,48 \%$, dan siswa menjawab pertanyaan (menulis) saat games tournament dengan Media Monopoli mengingkat persentasenya menjadi $89,66 \%$. Berikut ini disajikan data Aktivitas Belajar Akuntansi siklus I dan II:

Tabel 7. Aktivitas Belajar Akuntansi Siklus I dan Siklus II

\begin{tabular}{|c|c|c|c|c|}
\hline \multirow{2}{*}{$\begin{array}{c}\text { Indikat } \\
\text { or }\end{array}$} & \multicolumn{2}{|c|}{$\%$ Aktivitas } & \multicolumn{2}{c|}{$\begin{array}{c}\text { \% Peningkata } \\
\text { n }\end{array}$} \\
\cline { 2 - 5 } & $\begin{array}{c}\text { Siklu } \\
\text { s I }\end{array}$ & $\begin{array}{c}\text { Siklus } \\
\text { II }\end{array}$ & $\begin{array}{c}\text { Absol } \\
\text { ut }\end{array}$ & $\begin{array}{c}\text { Relat } \\
\text { if }\end{array}$ \\
\hline $\mathrm{a}$ & $\begin{array}{c}78,57 \\
\%\end{array}$ & $\begin{array}{c}93,10 \\
\%\end{array}$ & $\begin{array}{c}14,53 \\
\%\end{array}$ & $\begin{array}{c}18,50 \\
\%\end{array}$ \\
\hline $\mathrm{b}$ & 71,43 & 86,21 & 14,78 & 20,69 \\
& $\%$ & $\%$ & $\%$ & $\%$ \\
\hline $\mathrm{c}$ & 66,07 & 81,03 & 14,96 & 22,65 \\
& $\%$ & $\%$ & $\%$ & $\%$ \\
\hline $\mathrm{d}$ & 69,64 & 84,48 & 14,84 & 21,31 \\
& $\%$ & $\%$ & $\%$ & $\%$ \\
\hline $\mathrm{e}$ & 89,29 & 100,00 & 10,71 & 12,00 \\
& $\%$ & $\%$ & $\%$ & $\%$ \\
\hline $\mathrm{f}$ & 80,36 & 94,83 & 14,47 & 18,01 \\
& $\%$ & $\%$ & $\%$ & $\%$ \\
\hline
\end{tabular}




\begin{tabular}{|c|c|c|c|c|}
\hline \multirow{2}{*}{$\begin{array}{c}\text { Indikat } \\
\text { or }\end{array}$} & \multicolumn{2}{|c|}{$\%$ Aktivitas } & \multicolumn{2}{c|}{$\begin{array}{c}\text { \% Peningkata } \\
\text { n }\end{array}$} \\
\cline { 2 - 5 } & $\begin{array}{c}\text { Siklu } \\
\text { S I }\end{array}$ & $\begin{array}{c}\text { Siklus } \\
\text { II }\end{array}$ & $\begin{array}{c}\text { Absol } \\
\text { ut }\end{array}$ & $\begin{array}{c}\text { Relat } \\
\text { if }\end{array}$ \\
\hline $\mathrm{g}$ & $\begin{array}{c}85,71 \\
\%\end{array}$ & $\begin{array}{c}96,55 \\
\%\end{array}$ & $\begin{array}{c}10,84 \\
\%\end{array}$ & $\begin{array}{c}12,64 \\
\%\end{array}$ \\
\hline $\mathrm{h}$ & 76,79 & 91,38 & 14,59 & 19,01 \\
& $\%$ & $\%$ & $\%$ & $\%$ \\
\hline $\mathrm{i}$ & 83,93 & 98,28 & 14,35 & 17,09 \\
& $\%$ & $\%$ & $\%$ & $\%$ \\
\hline $\mathrm{j}$ & 75,00 & 89,66 & 14,66 & 19,54 \\
& $\%$ & $\%$ & $\%$ & $\%$ \\
\hline Rata- & 77,68 & 91,55 & 13,87 & 17,86 \\
rata & $\%$ & $\%$ & $\%$ & $\%$ \\
\hline
\end{tabular}

\section{Persentase Aktivitas Belajar}

Akuntansi Siklus I dan Siklus II

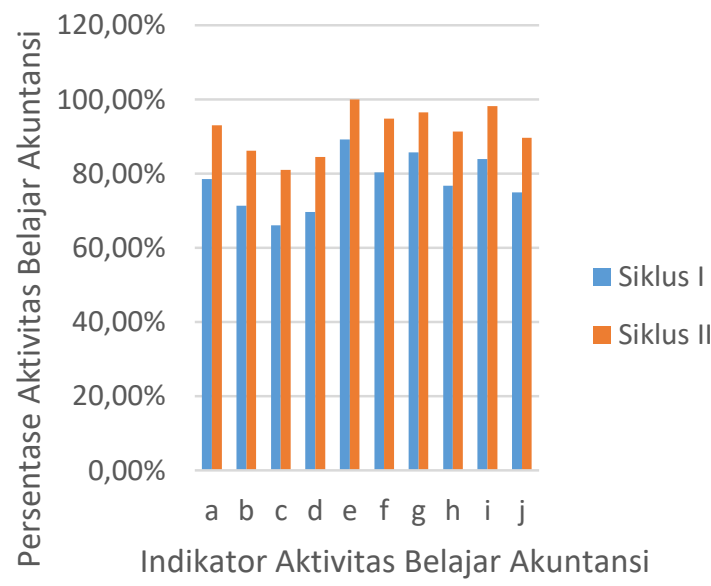

Gambar 1. Grafik Aktivitas Belajar Akuntansi Siklus I dan Siklus II

Tabel 7 dan gambar 1 tersebut menunjukkan bahwa pada masing-masing siklus terjadi peningkatan Aktivitas Belajar Akuntansi. Skor rata-rata Aktivitas Belajar Akuntansi pada siklus I sebesar 77,68 \%. Skor ini didapatkan dari skor Aktivitas Belajar Akuntansi dari setiap aspek yang terdapat pada indikator yang telah ditentukan. Beberapa indikator Aktivitas Belajar Akuntansi pada siklus I belum mencapai kriteria minimal yang ditentukan yaitu sebesar $75 \%$, sehingga tindakan dilanjutkan lagi sampai siklus II agar terjadi peningkatan pada Aktivitas Belajar Akuntansi. Setelah dilakukan tindakan siklus
II, skor rata-rata Aktivitas Belajar Akuntansi meningkat menjadi $91,55 \%$. Skor tersebut sudah mencapai kriteria minimal yang ditentukan dan semua indikator Aktivitas Belajar Akuntansi telah mencapai kriteria minimal, yaitu $75 \%$. Hasil di atas juga memperlihatkan bahwa terjadi peningkatan rata-rata skor Aktivitas Belajar Akuntansi dari siklus I ke siklus II sebesar 13,87 \%.

Jika dilihat dari Aktivitas Belajar Akuntansi pada siklus II secara individual, maka akan terlihat pengelompokan siswa berdasarkan Aktivitas Belajar Akuntansi seperti tertera di tabel 8 berikut ini:

Tabel 8. Pengelompokan Siswa Berdasarkan Aktivitas Belajar Akuntansi Siklus II

\begin{tabular}{|l|c|c|c|}
\hline Kriteria & $\begin{array}{c}\text { Skor } \\
\text { Aktivitas }\end{array}$ & $\begin{array}{c}\text { Jumlah } \\
\text { Siswa }\end{array}$ & Persentase \\
\hline $\begin{array}{l}\text { Sangat } \\
\text { Rendah }\end{array}$ & $0-4$ & - & $0 \%$ \\
\hline Rendah & $5-8$ & - & $0 \%$ \\
\hline Sedang & $9-12$ & - & $0 \%$ \\
\hline Tinggi & $13-16$ & 2 & $6,90 \%$ \\
\hline $\begin{array}{l}\text { Sangat } \\
\text { Tinggi }\end{array}$ & $17-20$ & 27 & $93,10 \%$ \\
\hline \multicolumn{2}{|c|}{ Jumlah } & 29 & $100,00 \%$ \\
\hline
\end{tabular}

Tabel 8 tersebut menunjukkan pengelompokan siswa berdasarkan Aktivitas Belajar Akuntansi siklus II. Berikut ini akan digambarkan pengelompokan siswa berdasarkan kriteria keberhasilan Aktivitas Belajar Akuntansi yaitu $\geq 75 \%$ atau dengan skor $\geq 15$.

Tabel 9. Pengelompokan Siswa Berdasarkan Ketuntasan Aktivitas Belajar Akuntansi Siklus II

\begin{tabular}{|l|c|c|c|}
\hline Kriteria & $\begin{array}{c}\text { Skor } \\
\text { Aktivitas }\end{array}$ & $\begin{array}{c}\text { Jumlah } \\
\text { Siswa }\end{array}$ & $\begin{array}{c}\text { Persen- } \\
\text { tase }\end{array}$ \\
\hline $\begin{array}{l}\text { Kurang } \\
\text { Aktif }\end{array}$ & $<15$ & - & $0 \%$ \\
\hline Aktif & $15-20$ & 29 & $100 \%$ \\
\hline \multicolumn{2}{|c|}{ Jumlah } & 29 & $100 \%$ \\
\hline
\end{tabular}

Berdasarkan tabel 9 tersebut terlihat bahwa secara individual Aktivitas Belajar 
Akuntansi telah mencapai kriteria yang telah ditentukan, yaitu $\geq 75 \%$. Seluruh siswa telah memperoleh skor Aktivitas Belajar Akuntansi $\geq 15$ atau $\geq 75 \%$, sehingga penelitian tindakan kelas dengan penerapan Model Pembelajaran Kooperatif tipe Teams Games Tournament (TGT) Berbantu Media Monopoli ini diakhiri sampai siklus II.

Dari pembahasan tersebut terlihat bahwa terjadi peningkatan skor per indikator dari siklus I ke siklus II. Hasil penelitian tersebut sejalan dengan penelitian relevan sebelumnya yaitu penelitian yang dilakukan oleh Irfan Dwi Jayanto pada penelitiannya tahun 2013 yang menyatakan bahwa penerapan Model Pembelajaran Kooperatif Tipe TGT dapat meningkatkan setiap indikator Aktivitas Belajar Akuntansi dari siklus I ke siklus II dengan peningkatan skor rata-rata Aktivitas Belajar Akuntansi sebesar $14,08 \%$ (relative) dan $11,09 \%$ (absolute), berasal dari skor rata-rata Aktivitas Belajar Akuntansi siklus I 78,891\% menjadi 90\% di siklus II. Kemudian penelitian yang dilakukan oleh Erma Wulandari pada tahun 2012 menyatakan pula bahwa penerapan Model Pembelajaran Kooperatif Tipe STAD Berbantu Media Monopoli dapat meningkatkan Aktivitas Belajar Akuntansi. Hal ini dibuktikan dengan hasil peningkatan Aktivitas Belajar Akuntansi dari sebelum penerapan sebesar $39,31 \%$ dilanjutkan hasil pada siklus I sebesar $67,43 \%$ dan pada siklus II $88,06 \%$. . Hal senada juga diungkapkan oleh Sigit Dwi Purwita pada penelitiannya tahun 2014 yang menyatakan bahwa penerapan Model Pembelajaran Kooperatif Tipe TGT dapat meningkatkan Aktivitas Belajar Akuntansi. Hal ini dibuktikan dengan terjadinya peningkatan rata-rata indikator Aktivitas Belajar Akuntansi pada siklus I sebesar $68,53 \%$ meningkat menjadi $81,47 \%$ pada siklus II. Oleh karena itu, penerapan Model Pembelajaran Kooperatif Tipe Teams Games Tournament (TGT) Berbantu Media Monopoli terbukti dapat meningkatkan Aktivitas Belajar Akuntansi Siswa Kelas XI AK2 SMK Negeri 1 Pengasih Tahun Ajaran 2016/2017.

\section{SIMPULAN DAN SARAN Simpulan}

Berdasarkan hasil penelitian dan pembahasan dapat disimpulkan bahwa penerapan Model Pembelajaran Kooperatif Tipe TGT Berbantu Media Monopoli dapat meningkatkan Aktivitas Belajar Akuntansi Siswa Kelas XI AK2 SMK Negeri 1 Pengasih Tahun Ajaran 2016/2017 yang dibuktikan dengan adanya peningkatan persentase rata-rata Aktivitas Belajar Akuntansi yang diambil melalui observasi dengan menggunakan lembar observasi. Skor persentase rata-rata Aktivitas Belajar Akuntansi telah mencapai indikator keberhasilan Aktivitas Belajar Akuntansi lebih dari $75 \%$ yaitu sebesar $77,68 \%$ pada siklus I dan 91,55\% pada siklus II. Terjadi peningkatan dari siklus I ke siklus II sebesar $17,86 \%$ (relatif) dan 13,87\% (absolut). Hasil rata-rata Aktivitas Belajar Akuntansi di siklus II menunjukkan bahwa skor tersebut sudah mencapai kriteria minimal yang ditentukan yaitu sebesar $75 \%$.

Terdapat 10 indikator Aktivitas Belajar Akuntansi dalam penelitian ini dan kesepuluh indikator tersebut telah mencapai kriteria minimal yang ditentukan yaitu $75 \%$. Selain itu secara individual skor Aktivitas Belajar Akuntansi yang diperoleh masingmasing siswa juga telah mencapai kriteria minimal yaitu $75 \%$.

\section{Saran}

a. Bagi Guru Akuntansi SMK Negeri 1 Pengasih:

1) Perlunya inovasi dalam pelaksanaan proses pembelajaran. Pemilihan metode pembelajaran harus disesuaikan karakteristik dan kemampuan siswa, agar KBM dapat terlaksana dengan lancar.

2) Guru dapat menerapkan Model Pembelajaran Kooperatif Tipe TGT Berbantu Media Monopoli sebagai salah satu alternatif pembelajaran akuntansi untuk meningkatkan Aktivitas Belajar Akuntansi, dikarenakan adanya peningkatan 
Aktivitas Belajar Akuntansi setelah menerapkan model pembelajaran yang dibuktikan dengan hasil penelitian.

b. Bagi Peneliti Selanjutnya:

1) Diharapkan mampu memperbaiki aspek-aspek yang diamati dalam aktivitas belajar sehingga dapat menunjukkan peningkatan Aktivitas Belajar Akuntansi secara keseluruhan.

2) Diharapkan dapat membuat Media Monopoli berupa software agar menambah jenis media pembelajaran secara modern.

3) Diharapkan dapat menerapkan Media Monopoli pada materi pelajaran Akuntansi lainnya.

\section{DAFTAR PUSTAKA}

Arif Rohman. (2013). Memahami Ilmu Pendidikan. Yogyakarta : CV Aswaja Pressindo.

Depdikbud. (2003). Undang-Undang No. 20 Tahun 2003 tentang Sistem Pendidikan Nasional. Diambil dari http://www.dikti.go.id/files/atur/UU20 -2003Sisdiknas.pdf tanggal 10 Mei 2016.

Dwi Siswoyo, dkk. (2013). Ilmu Pendidikan. Yogyakarta: UNY Press.

Sardiman A.M. (2011). Interaksi dan Motivasi Belajar Mengajar. Jakarta: PT Raja Grafindo Persada.

Slavin E. Robert. (2010). Cooperative Learning. Teori, Riset, dan Praktik. Bandung: Nusa Media.

Wina Sanjaya. (2014). Strategi Pembelajaran Berorientasi Standar Proses Pendidikan. Jakarta: Kencana Prenadamedia Group. 